the contrary, in my specimen, comparatively large (especially so upon the left side, c.a, fig. 5)-relatively larger, in fact, than in the healthy individual of the Common Frog prior to hibernation. In consideration of all the facts, I think it probable that Espada was mistaken, and that this extraordinary paternal instinct does not lead up to that self-abnegation which he supposed.

\title{
3. Description of a new Genus and Species of Rat from New Guinea. By Oldfield Thomas.
}

[Received March 27, 1888.]

Among the collections recently brought from New Guinea by $\mathrm{Mr}$. H. O. Forbes there occurs a specimen of Rat strongly resembling, superficially, the common small Papuan Uromys, U. cervinipes, Gould, but showing on a closer examination such characters, both external and cranial, as to necessitate the formation of a special genus for its reception : of these characters by far the most striking is its possession of a tail modified for prehension in the same fashion ${ }^{1}$, and almost to the same extent, as in the Phalangers inhabiting the same country. Among the other members of the Myomorpha, so far as I know, the only ones that have a truly prehensile tail are Dendromys and the common Harvest-Mouse (Mus minutus), in each of which there is a tendency towards the same modification of the tail as in the present animal. Otherwise, among the whole of the Rodents, this character is only found in the South-American Porcupines. It is true that many other Rats and Mice have the power of twisting their tails round branches, and so helping themselves in climbing, but in none is this so far developed as to cause any important modification in the actual structure of the tail, as is the case in the animal now described.

The teeth, again, are remarkably complicated, and show a high degree of specialization, far more than is found in any other genus at all allied to the present one. This extreme specialization both of teeth and tail is especially remarkable in an animal inhabiting such a refuge for old and little-modified forms as New Guinea.

'The following is a detailed description of the new form :-

\section{Chiruromys, g. n.}

Externally like $M u s$, but with the terminal portion of the tail above without scales, quite naked, transversely wrinkled, and obviously prehensile. Scales of rest of tail (fig. 2, c) not, as is usual, square and arranged in distinct rings, but more or less pentagonal or lozengeshaped, and set in diagonal slanting series, somewhat like the dorsal scales of a snake.

Skull (fig. 1, p. 238) with the infraorbital foramen typical in shape, but with its external wall narrow and not produced forwards as a projecting plate. Anterior part of zygomata projecting outwards

1 Except that the curl is upwards instead of downwards.

Proc. Zool. Soc.-1888, No. XVII. 
nearly at right angles to the general line of the skull. Supraorbital edges square and sharp, but not beaded. Palatine foramina short and narrow. Bullæ small.

Teeth.-Incisors smooth. Upper molars (fig. 2, A) very compliFig. 1.

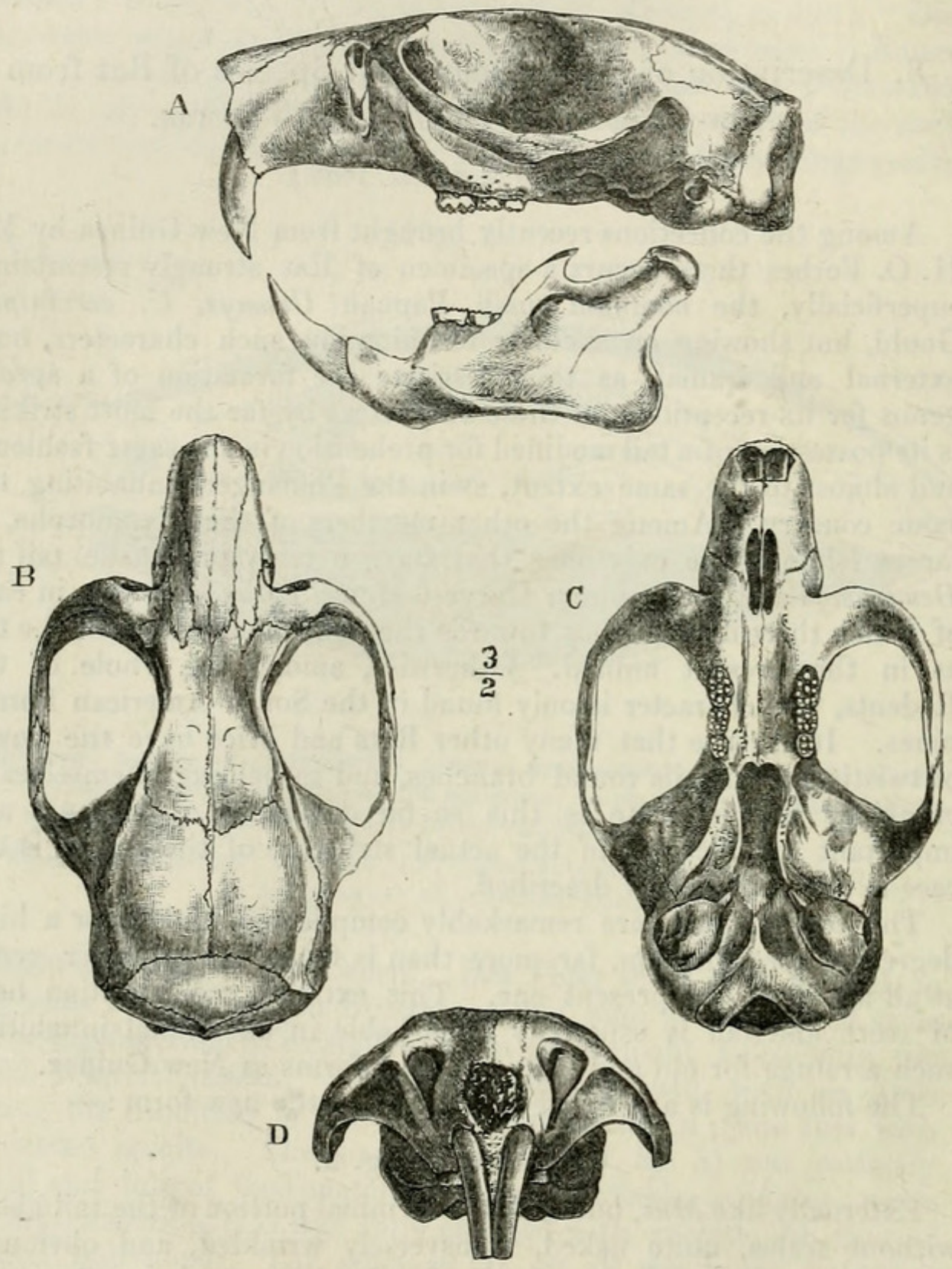

Skull of Chiruromys forbesi; once and a half the natural size.

cated, the cusps low and the laminæ scarcely marked, so that the homologies between their cusps and those found in other genera are by no means clear. $\mathrm{M}^{1}$ with eleven cusps in all, namely three transverse sets of three each, and two extra solitary cusps; $\mathrm{m}^{2}$ with 10 cusps; $\underline{\mathrm{m}}^{3}$ nearly as long as $\underline{\mathrm{m}}^{2}$, apparently with seven cusps, but its 
pattern too vague and little defined for exact description. Lower $\mathrm{m}^{1}$ (fig. 2, в) with three pairs of transversely elongated cusps, an anterior and posterior central cusp, and a long extra external ledge running the whole length of the tooth; $\overline{\mathrm{m}^{2}}$ with two pairs of similar cusps, a single posterior central one, and an external ledge; $\overline{\mathrm{m}^{3}}$ with two pairs of cusps and an antero-external ledge.

Chiruromys forbesi, sp. n.

Very similar to Uromys cervinipes, Gould, in size and general appearance. Colour above a uniform dull rufous grey, below buff,

Fig. 2.
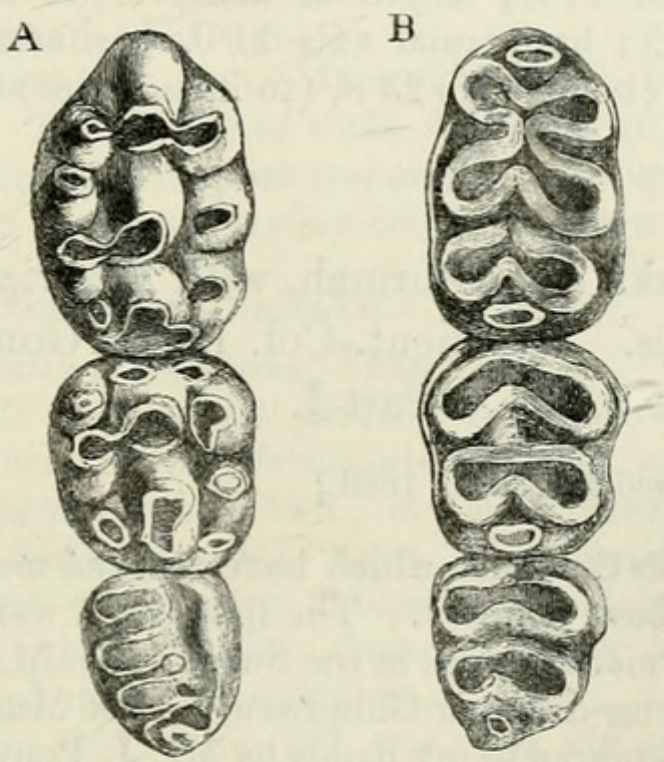

C

D
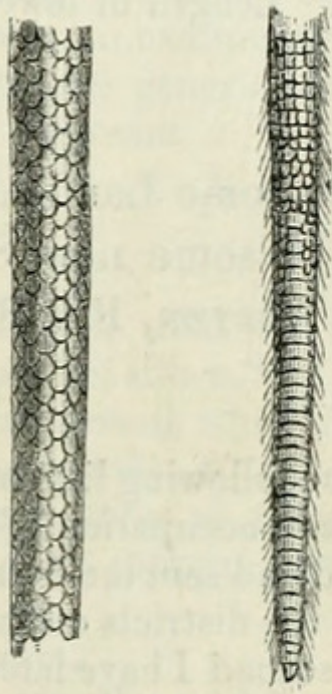

Chiruromys forbesi.

A, left upper, and в. left lower molars, magnified about 10 diameters; c, dorsal view of middle, and $\mathrm{D}$, tip of tail to show arrangement of scales.

the line of demarcation fairly sharply defined; a ring round each eye nearly black; between eye and ear, rather above their level, is a prominent white spot; whiskers very numerous, long and coarse, shining black, a single bristle also inserted just above each eye. Ears rather small, laid forward they reach to just beyond the middle of the eye, narrow, not pointed, their anterior edge straight, their tips and posterior margins erenly convex; quite naked inside and terminally outside. Palate-ridges seven, three anterior undivided and four interdental. Hallux rudimentary, with a broad nail; palms with five broad smooth pads. Soles quite naked, smooth, with six large low pads, the posterior pads elongated; fifth hind toe reaching to the base of the last phalanx of the fourth. Tail (fig. 2, c and D) longer than the head and body, scaly, with minute hairs between the scales, its terminal inch or inch and a half quite naked and without scales above, the tip with a natural curl upwards and thus showing, as well as by its structure, the prehensile power it possesses ; scales large, averaging rather more than a millimeter in diameter; arranged, 
as above described. Mammæ six, one axillary and two inguinal pairs. Skull and teeth as described above.

Hab. Sogere, S.E. New Guinea; altitude 1750 feet.

Dimensions of the type, an adult female, in spirit:-Head and body 156 millim.; tail 222 ; hind foot 30 ; fore arm and hand 42.5 ; ear (above crown) 17 ; head 43 ; muzzle to eye 18.8 , to ear 35.5 ; heel to front of last foot-pad 15 ; length of the pad 6.8 .

Skull.-Basal length $34 \cdot 0$, greatest breadth $22 \cdot 8$; nasals, length $12 \cdot 3$; interorbital breadth $5 \cdot 7$; interparietal, length $4 \cdot 8$, breadth $9 \cdot 3$; infraorbital foramen, height $5 \cdot 8$, length of outer wall 4.0 , distance from its outer corner to that of its fellow 11.0 ; palate, length $20 \cdot 0$, breadth outside $\mathrm{m}^{1} 7 \cdot 0$, inside $\mathrm{m}^{1} 4 \cdot 0$; palatal foramen, length 5.2 ; diastema, length 11.3 ; length of molar series 5.5 , of $\mathrm{m}^{1} 2 \cdot 5$, of $\mathrm{m}^{2} 1 \cdot 7$, of $\mathrm{m}^{3} 1 \cdot 5$; basicranial axis $11 \cdot 0$, basifacial axis $\overline{23} \cdot 0$. Length of lower jaw (bone only) $23 \cdot 8$, (to incisor tips) $27 \cdot 0$.

4. On some Land-Mollusks from Burmah, with Descriptions of some new Species. By Lieut.-Col. H. H. GodwinAusten, F.R.S., F.Z.S., \&c.-Part I.

[Received March 23, 1888.]

The following list comprises the shells which have reached me since our late occupation of the above country. The first batch were collected and sent me by my former assistant in the Survey, Mr. M.Ogle, from the districts on the Kyeng-dwen, or Chindwen, east of Munipur. The second I have lately had placed in my hands by Mr. J. Ponsonby, who received them from Captain Spratt, R.A., from Upper Burmah, where that officer has been employed during the late military expeditions. The shells are not in a good state of preservation, and no doubt were collected under very considerable difficulties as regards leisure and deficiency of carriage. There are many new forms, showing what a rich harvest awaits the naturalists who could devote more time and care to the work. We trust that Captain Spratt (son of Admiral Spratt, a life-long worker at the Mollusca) will yet be able to add still more to our knowledge of the species to be found in our newly acquired territory.

I propose in this communication to describe the shells collected by Captain Spratt. Hlindet, where most of them were obtained, is situated on a tributary of the Irrawaddy, which, rising in the hills south of Mandalay, flows north to join that river at the sharp bend below that town. It is through this valley that the new line of railway is to run to the capital from Toungoo.

The late Mr. Francis Fedden, of the Geological Surrey, visited this part of Burmah and the Salwin valley, in 1864-65, and brought back with him a good many specimens of land-shells, which were described by Mr. W. Theobald in the Journal of the Asiatic Society for 1870 . 


\section{$2 \mathrm{BHL}$ Biodiversity Heritage Library}

Thomas, Oldfield. 1888. "Description of a new Genus and Species of Rat from New Guinea." Proceedings of the Zoological Society of London 1888, 237-240. https://doi.org/10.1111/j.1469-7998.1888.tb06700.x.

View This Item Online: https://www.biodiversitylibrary.org/item/99299

DOI: https://doi.org/10.1111/j.1469-7998.1888.tb06700.x

Permalink: https://www.biodiversitylibrary.org/partpdf/72953

\section{Holding Institution}

Natural History Museum Library, London

\section{Sponsored by}

Natural History Museum Library, London

\section{Copyright \& Reuse}

Copyright Status: Public domain. The BHL considers that this work is no longer under copyright protection.

This document was created from content at the Biodiversity Heritage Library, the world's largest open access digital library for biodiversity literature and archives. Visit BHL at https://www.biodiversitylibrary.org. 